\title{
Analisis Kandungan Mineral dari Lumpur Panas Sidoarjo sebagai Potensi Sumber Silika dan Arah Pemanfaatannya
}

Endang Ciptawati ${ }^{\mathrm{a},}{ }^{,}$, Mohammad Hilfi Azra Dzikrulloh ${ }^{\mathrm{a}}$, Maya Oki Septiani ${ }^{\mathrm{a}}$, Viska Rinata ${ }^{\mathrm{b}}$, Deni Ainur Rokhima,d, Nabilah AzfaFauziyyaha ${ }^{\mathrm{a}}$, Dinda Sribuana ${ }^{\mathrm{c}}$

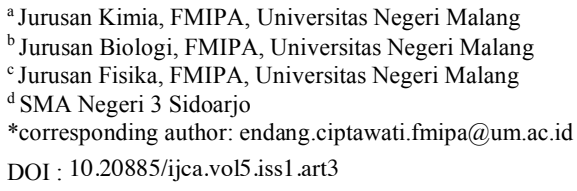

\begin{tabular}{|c|c|}
\hline ARTIKEL INFO & ABSTRAK \\
\hline $\begin{array}{ll}\text { Diterima } & : 03 \text { November } 2021 \\
\text { Direvisi } & : 01 \text { Desember } 2021 \\
\text { Diterbitkan } & : 01 \text { Maret } 2022 \\
\text { Kata kunci : Lumpur Panas } \\
\text { Sidoarjo, Silika, Uji XRD, Uji } \\
\text { XRF, Mineral }\end{array}$ & $\begin{array}{l}\text { Lumpur panas Sidoarjo merupakan salah satu bencana luapan lumpur } \\
\text { panas yang memiliki dampak signifikan di Indonesia terhitung sejak } 29 \\
\text { Mei } 2006 \text {. Adanya bencana ini banyak menimbulkan kerugian } \\
\text { kesehatan, lingkungan hingga ekonomi. Akan tetapi, dibalik kerugian } \\
\text { tersebut ternyata terdapat banyak kandungan mineral dalam lumpur } \\
\text { luapan yang dapat dimanfaatkan sebagai sumber silika. Penelitian ini } \\
\text { bertujuan untuk mengetahui kandungan mineral terutama silika dalam } \\
\text { lumpur panas Sidoarjo yang dapat berpotensi sebagai sumber silika } \\
\text { sintesis. Sampel diambil pada permukaan lumpur panas Sidoarjo dengan } \\
\text { radius } 500 \mathrm{~m}, 1000 \mathrm{~m} \text {, dan } 1500 \mathrm{~m} \text { dari pusat semburan. Instrumen yang } \\
\text { digunakan adalah XRF (X-Ray Fluorescence) dan XRD (X-Ray } \\
\text { Diffraction) dimana sampel ditempatkan dalam sample holder dan } \\
\text { diradiasi menggunakan sinar-X. Berdasarkan uji XRF, pada masing- } \\
\text { masing radius diperoleh kandungan silika sebesar } 45,0 \% \text { (radius } 500 \text { m), } \\
45,3 \% \text { (radius } 1000 \text { m), dan } 43,3 \% \text { (radius } 1500 \text { m) yang merupakan } \\
\text { senyawa oksida dengan kandungan terbesar. Hasil uji XRD juga } \\
\text { menunjukkan kesesuaian dengan hasil uji XRF, dimana fase yang paling } \\
\text { dominan dalam lumpur panas Sidoarjo pada semua radius adalah fase } \\
\text { kuarsa (SiO }{ }_{2} \text { ). Berdasarkan kedua hasil ini, dapat disimpulkan bahwa } \\
\text { kandungan mineral lumpur panas Sidoarjo pada } 3 \text { radius berbeda } \\
\text { memiliki kandungan yang relatif sama dan dapat berpotensi sebagai } \\
\text { sumber silika yang bermanfaat dalam bidang diantaranya sebagai } \\
\text { adsorben logam berat, bidang pertanian, hingga katalis. }\end{array}$ \\
\hline
\end{tabular}

\section{ARTICLE INFO}

Received :03 November 2021

Revised :01 December 2021

Published : 01 March 2022

Keywords : Sidoarjo Hot Mud,

Silica, XRD Test, XRF Test,

Mineral

\begin{abstract}
Sidoarjo hot mud is one of the hot mudflow disasters that has had a significant impact in Indonesia since May 29, 2006. This disaster caused a lot of health, environmental and economic losses. However, behind these losses, it turns out that there is a lot of mineral content in the overflow mud that can be used as a source of silica. This study aims to determine the mineral content, especially silica in Sidoarjo hot mud which can be a potential source of synthetic silica. Samples were taken on the Sidoarjo hot mud surface with a radius of $500 \mathrm{~m}, 1000 \mathrm{~m}$, and $1500 \mathrm{~m}$ from the center of the eruption. The instruments used are XRF (X-Ray Fluorescence) and XRD (X-Ray Diffraction) where the sample is placed in a sample holder and irradiated using X-rays. Based on the
\end{abstract}


XRF test, in each radius obtained silica content of $45.0 \%$ (radius 500 $\mathrm{m}$ ), $45.3 \%$ (radius $1000 \mathrm{~m}$ ), and $43.3 \%$ (radius $1500 \mathrm{~m}$ ) which is the oxide compound with the largest content. The XRD test results also show conformity with the XRF test results, where the most dominant phase in Sidoarjo hot mud at all radii is the quartz phase $\left(\mathrm{SiO}_{2}\right)$. Based on these two results, it can be concluded that the mineral content of Sidoarjo hot mud at 3 different radii has relatively the same content and can potentially be a useful source of silica in the fields of heavy metal adsorbents, agriculture, and catalysts.

\section{PENDAHULUAN}

Sumber luapan lumpur panas Sidoarjo berlokasi di Kecamatan Porong, tepatnya pada jarak 100-150 meter dari sumur eksplorasi Banjar Panji-1 di lokasi pertambangan gas PT. Lapindo Brantas di Kelurahan Siring, Kecamatan Porong, Kabupaten Sidoarjo. Luapan lumpur tersebut mengandung banyak material vulkanis bercampur gas, sehingga dapat disebut mud volcano [1]. Lumpur panas Sidoarjo menimbulkan kerugian kesehatan, lingkungan, hingga ekonomi, terutama bagi masyarakat warga Porong. Namun, dibalik dampak yang ditimbulkan, lumpur panas Sidoarjo memiliki potensi untuk dimanfaatkan menjadi sesuatu yang bernilai guna, jika ditinjau dari segi struktur morfologi maupun kandungannya. Beberapa peneliti telah mencoba memanfaatkan lumpur panas Sidoarjo, salah satunya sebagai bahan baku batu bata [2],[3].

Pengetahuan karakteristik lumpur panas Sidoarjo sangat dibutuhkan dalam pemanfaatan dan pengelolaannya. Lumpur panas Sidoarjo diklasifikasikan sebagai tanah lempung lembek berlanau dengan kandungan air yang tinggi dan berbagai elemen mineral lainnya [4]. Salah satu kandungan lumpur panas Sidoarjo yang sangat potensial adalah silika [5]. Silika merupakan hasil polimerisasi asam silikat, yang terbentuk dari rantai $\mathrm{SiO}_{4}$ tetrahedral dengan formula umum $\mathrm{SiO}_{2}$. Di alam, senyawa ini ditemukan pada beberapa bahan alam seperti kuarsa dan pasir [6].

Penggunaan dan kebutuhan silika mengalami peningkatan seiring terjadinya peningkatan kebutuhan perindustrian. Hal tersebut berlaku bagi perkembangan teknologi global yang menggunakan logam silikon sebagai bahan dasar. Data Badan Pusat Statistik 2018 menyebutkan bahwa impor silika pada tahun 2016 mengalami peningkatan menjadi $40.400 .503 \mathrm{Kg}$ dari yang semula 39.645.447 Kg pada tahun 2015. Hal tersebut menunjukkan bahwa produksi silika belum mampu mencukupi kebutuhan silika dalam negeri. Silika merupakan material yang banyak dimanfaatkan dalam bidang industri, contohnya yaitu sebagai material pembuatan chip, industri ban, karet, keramik, semen, elektronik, kosmetik, cat, film, pasta gigi, dan pembuat beton [7]. Silika juga dapat dimanfaatkan sebagai adsorben logam berat [8], campuran pupuk [9], dan prekursor sintesis zeolit [10]. Fungsi silika yang krusial tersebut harus diimbangi dengan ketersediaannya di alam. Kandungan silika yang merupakan komponen utama pada lumpur panas Sidoarjo berpotensi menjadi sumber silika alternatif. Gambar 1 menunjukkan lokasi pengambilan sampel dilakukan pada beberapa titik dari pusat semburan meliputi radius 500, 1000, dan 1500 meter dari pusat semburan yang bertujuan supaya memperoleh data yang representatif terkait mineral yang terkandung dalam lumpur panas Sidoarjo.

Dalam penelitian ini dilakukan analisis terhadap kandungan lumpur panas Sidoarjo sebagai potensi sumber silika dan arah pemanfaatannya. Metode yang digunakan adalah difraksi sinar-X menggunakan instrumen XRF (X-Ray Fluorescence) dan XRD (X-Ray Diffraction). Selain itu, penelitian ini juga mengkaji struktur silika (amorf atau kristalin) yang terdapat dalam lumpur panas Sidoarjo. Hasil penelitian ini diharapkan dapat memberi pengetahuan kepada masyarakat terkait pemberdayaan lumpur panas Sidoarjo yang berpotensi sebagai sumber silika dan arah pemanfaatan kedepannya. 


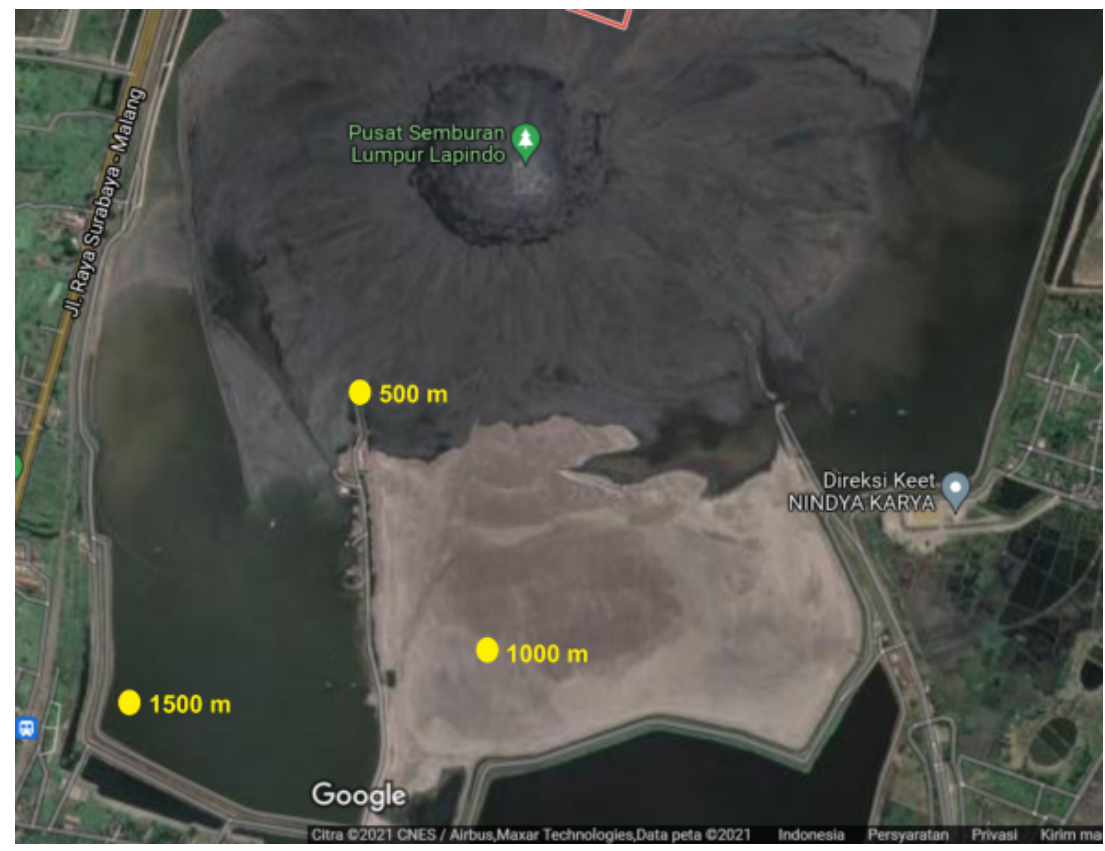

Gambar 1. Mapping pengambilan sampel lumpur panas Sidoarjo

\section{METODE}

\subsection{Alat dan Bahan}

Alat-alat yang digunakan dalam penelitian ini adalah mortar, alu dan ayakan 30 mesh. Sementara itu dalam karakterisasi X-Ray Diffraction (XRD) merk PanAnalytical dengan tipe E'xpert Pro dan X-Ray Fluorescence (XRF) merk PanAnalytical dengan tipe Minipal 4 digunakan alat yang ada pada Laboratorium Mineral dan Material Maju Universitas Negeri Malang. Adapun bahan-bahan yang digunakan adalah akuades dan sampel lumpur panas Sidoarjo.

\subsection{Prosedur Kerja}

\subsubsection{Preparasi Sampel}

Sampel yang digunakan adalah lumpur panas Sidoarjo di Kecamatan Porong, Kabupaten Sidoarjo. Sampel diambil pada permukaan endapan lumpur dengan 3 radius berbeda yaitu $500 \mathrm{~m}$, $1000 \mathrm{~m}$, dan $1500 \mathrm{~m}$ dari pusat semburan. Sampel terlebih dahulu dibersihkan dari sampah-sampah besar seperti plastik, kain, dan sejenisnya.

Sampel kemudian dicuci dengan akuades dengan tujuan untuk menghilangkan unsur pengotor. Kemudian dikeringkan langsung di bawah sinar matahari sampai kering. Setelah itu, dihaluskan menggunakan mortar, kemudian diayak menggunakan ayakan 30 mesh untuk mendapatkan ukuran partikel yang sejenis/homogen. Langkah selanjutnya adalah melakukan pengujian XRD dan XRF pada masing-masing sampel.

\subsubsection{Analisis Kandungan Menggunakan XRF}

Analisis kandungan mineral lumpur panas Sidoarjo menggunakan XRF dilakukan dengan cara dimasukkan sampel yang telah kering ke dalam sample holder. Kemudian sampel diradiasi dengan sinar-X (X-Ray). Data yang diperoleh dari analisis menggunakan XRF ini, dapat ditentukan kadar kandungan mineral dalam sampel lumpur panas Sidoarjo.

\subsubsection{Analisis Kandungan Menggunakan XRF}

Analisis kandungan mineral menggunakan XRD, yang dilakukan dengan cara dimasukkan sampel berupa serbuk ke dalam sample holder. Kemudian diratakan permukaannya dan dimampatkan dengan bantuan alat tekan/pressing. Selanjutnya, tempat sampel tersebut diletakkan pada pemegangnya tempat sampel. Sampel dikenai sinar- $\mathrm{X}$ dengan sumber radiasi $\mathrm{Cu}$ dengan 
rentang sudut $2 \theta, 10^{\circ}-90^{\circ}$ sehingga terjadi difraksi dengan pola tertentu yang dibuktikan pada hasil difraktogram. Data yang diperoleh diidentifikasi dengan cara membandingkan nilai $d$-spacing dari sampel dengan beberapa data standar mineral yang sudah ada, selain itu data dianalisis kuantitatif sederhana dengan bantuan aplikasi Match! 3.

\section{HASIL PENELITIAN}

Analisis kandungan senyawa dalam sampel lumpur panas Sidoarjo terdiri dari analisis kandungan unsur beserta senyawa oksidanya menggunakan uji XRF dan kandungan mineral menggunakan uji XRD. Uji XRF digunakan dalam menganalisis unsur beserta senyawa oksida yang membentuk material dengan prinsip adanya interaksi material tersebut dengan sinar-X [11]. Uji XRF ini sering kali digunakan dalam analisis mineral hal ini dikarenakan uji ini cepat, akurat, tidak merusak, dan biasanya hanya membutuhkan persiapan sampel yang minimal [12]. Sedangkan uji XRD digunakan dalam menentukan fase dan struktur kristal dengan prinsip adanya interaksi material analit tersebut dengan sinar-X. Prinsip dasar uji XRD adalah mendifraksi cahaya yang melalui celah kristal. Selain itu, juga menerapkan hukum Bragg yang menyatakan terdapatnya perbedaan lintasan berkas difraksi sinar-X yang merupakan kelipatan panjang gelombang dengan perumusan $\mathrm{n} \lambda=\mathrm{d} \sin$ $\theta$ dengan $n$ merupakan bilangan bulat, $\lambda$ adalah panjang gelombang sinar- $X$, $d$ adalah jarak antar bidang, dan $\theta$ adalah sudut difraksi. Gambar 2, 3, dan 4 menunjukkan sampel lumpur Panas Sidoarjo yang dianalisis yang diambil dari berbagai radius.

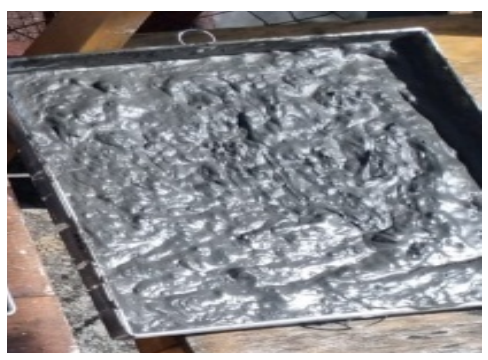

Gambar 2. Sampel dari radius 500 meter

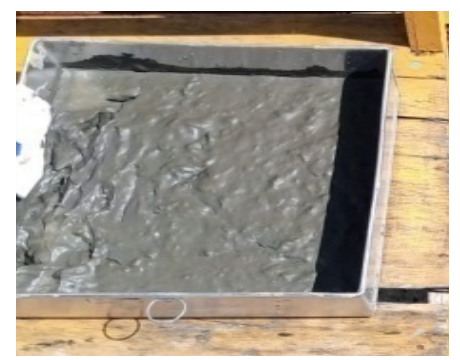

Gambar 3.Sampel dari radius 1000 meter

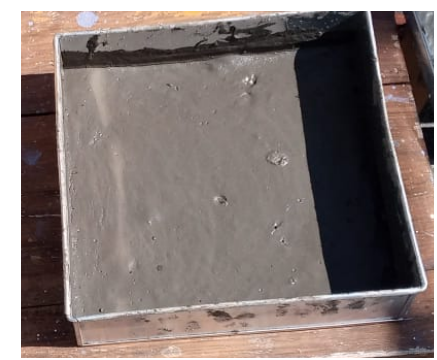

Gambar 4.Sampel dari radius 1500 meter

\subsection{Hasil Uji XRF}

Hasil analisis kandungan unsur dalam lumpur panas Sidoarjo pada radius $500 \mathrm{~m}, 1000 \mathrm{~m}$, dan $1500 \mathrm{~m}$ dari pusat semburan ditunjukkan pada Tabel 1. Berdasarkan Tabel 1, kandungan unsur terbesar dalam lumpur panas Sidoarjo adalah Besi ( $\mathrm{Fe}$ ) sebesar 34,2 \% (radius $500 \mathrm{~m}$ ), 33,9\% (radius $1000 \mathrm{~m}$ ), dan 36,4\% (radius $1500 \mathrm{~m}$ ). Kandungan terbesar kedua adalah silikon (Si) sebesar 32,7 \% (radius $500 \mathrm{~m}$ ), 33,0 \% (radius $1000 \mathrm{~m}$ ), dan 31,1\% (radius $1500 \mathrm{~m}$ ). Unsur lain yang terdapat di dalamnya adalah $\mathrm{Al}, \mathrm{K}, \mathrm{Ca}, \mathrm{Ti}, \mathrm{V}, \mathrm{Cr}, \mathrm{Mn}, \mathrm{Ni}, \mathrm{Cu}, \mathrm{Zn}, \mathrm{Br}, \mathrm{Sr}, \mathrm{Mo}, \mathrm{Eu}, \mathrm{Yb}, \mathrm{Re}$, dan $\mathrm{P}$. Kandungan unsur silikon pada penelitian ini sedikit lebih besar dari hasil analisis awal yang dilakukan oleh Assolah (2015) yang memperoleh kandungan unsur Si sebesar 19,70\%. Menurut Juniawan, dkk (2012), lumpur panas Sidoarjo memiliki fraksi pasir dan liat mencapai $60 \%$ dari keseluruhan fraksinya [14], Dimana secara umum fraksi pasir sendiri terbentuk dari mineral silika kuarsa dan fraksi liat mengandung leburan silika yang halus [15], [16]. Hal inilah yang menyebabkan kandungan Si pada lumpur panas Sidoarjo menjadi yang paling dominan di antara lainnya. Selain menganalisis kandungan unsur pada lumpur panas Sidoarjo, analisis XRF ini juga menganalisis kandungan oksidanya yang ditunjukkan pada Tabel 2.

Berdasarkan Tabel 2. maka kandungan oksida yang paling dominan dalam lumpur panas Sidoarjo adalah silika oksida sebesar 45,0\% (radius $500 \mathrm{~m}$ ), 45,3\% (radius $1000 \mathrm{~m}$ ), dan 43,3\% (radius $1500 \mathrm{~m}$ ). Kandungan yang dominan kedua adalah oksida besi yakni sebesar $24,1 \%$ (radius $500 \mathrm{~m}$ ), 23,7\% (radius $1000 \mathrm{~m}$ ), dan 25,9\% (radius $1500 \mathrm{~m}$ ), hal inilah yang menyebabkan lumpur panas Sidoarjo berwarna abu-abu kehitaman. Oksida lain yang terdapat di dalamnya adalah $\mathrm{Al}_{2} \mathrm{O}_{3}$, $\mathrm{K}_{2} \mathrm{O}, \mathrm{CaO}, \mathrm{TiO}_{2}, \mathrm{VO}_{5}, \mathrm{Cr}_{2} \mathrm{O}_{3}, \mathrm{MnO}, \mathrm{NiO}, \mathrm{CuO}, \mathrm{ZnO}, \mathrm{SrO}, \mathrm{MoO}_{3}, \mathrm{Eu}_{2} \mathrm{O}_{3}, \mathrm{Yb}_{2} \mathrm{O}_{3}, \mathrm{Re}_{2} \mathrm{O}_{7}$, dan $\mathrm{P}_{2} \mathrm{O}_{5}$. Dengan demikian, lumpur panas Sidoarjo ini berpotensi dijadikan sebagai sumber silika kedepannya 
dan dapat juga dilakukan pengeksplorasian lebih lanjut dikarenakan terdapatnya mineral tanah jarang yang teridentifikasi.

TABEL I. Hasil analisis kandungan unsur dalam Lumpur Panas Sidoarjo menggunakan XRF

\begin{tabular}{cccc}
\hline Unsur & $\begin{array}{c}\text { Persentase (\%) } \\
(\text { Radius } 500 \mathrm{~m})\end{array}$ & $\begin{array}{c}\text { Persentase }(\%) \text { (Radius } \\
1000 \mathrm{~m})\end{array}$ & $\begin{array}{c}\text { Persentase (\%) (Radius } 1500 \\
\text { ) }\end{array}$ \\
\hline $\mathrm{Al}$ & $11 \%$ & $11 \%$ & $9,9 \%$ \\
$\mathrm{Si}$ & $32,7 \%$ & $33,0 \%$ & $31,1 \%$ \\
$\mathrm{~K}$ & $4,03 \%$ & $3,88 \%$ & $3,81 \%$ \\
$\mathrm{Ca}$ & $7,78 \%$ & $8,19 \%$ & $7,99 \%$ \\
$\mathrm{Ti}$ & $2,13 \%$ & $2,11 \%$ & $2,20 \%$ \\
$\mathrm{~V}$ & $0,081 \%$ & $0,087 \%$ & $0,087 \%$ \\
$\mathrm{Cr}$ & $0,100 \%$ & $0,099 \%$ & $0,11 \%$ \\
$\mathrm{Mn}$ & $0,45 \%$ & $0,47 \%$ & $0,53 \%$ \\
$\mathrm{Fe}$ & $34,2 \%$ & $33,9 \%$ & $36,4 \%$ \\
$\mathrm{Ni}$ & $0,03 \%$ & - & - \\
$\mathrm{Cu}$ & $0,15 \%$ & $0,14 \%$ & $0,16 \%$ \\
$\mathrm{Zn}$ & $0,08 \%$ & $0,07 \%$ & $0,07 \%$ \\
$\mathrm{Br}$ & $0,39 \%$ & $0,31 \%$ & - \\
$\mathrm{Sr}$ & $1,1 \%$ & $1,1 \%$ & $0,86 \%$ \\
$\mathrm{Mo}$ & $5,1 \%$ & $5,1 \%$ & $5,4 \%$ \\
$\mathrm{Eu}$ & $0,59 \%$ & $0,58 \%$ & $0,67 \%$ \\
$\mathrm{Yb}$ & $0,1 \%$ & - & - \\
$\mathrm{Re}$ & $0,2 \%$ & $0,2 \%$ & $0,3 \%$ \\
$\mathrm{P}$ & - & - & $0,44 \%$ \\
\hline
\end{tabular}

TABEL II. Hasil analisis kandungan oksida dalam Lumpur Panas Sidoarjo menggunakan XRF

\begin{tabular}{cccc}
\hline Oksida & $\begin{array}{c}\text { Persentase (\%) } \\
(\text { Radius } 500 \mathrm{~m})\end{array}$ & $\begin{array}{c}\text { Persentase }(\%) \\
(\text { Radius } 1000 \mathrm{~m})\end{array}$ & Persentase (\%) (Radius 1500 m) \\
\hline $\mathrm{Al}_{2} \mathrm{O}_{3}$ & $14 \%$ & $14 \%$ & $13 \%$ \\
$\mathrm{SiO}_{2}$ & $45,0 \%$ & $45,3 \%$ & $43,3 \%$ \\
$\mathrm{~K}_{2} \mathrm{O}$ & $2,76 \%$ & $2,64 \%$ & $2,64 \%$ \\
$\mathrm{CaO}$ & $6,05 \%$ & $6,34 \%$ & $6,30 \%$ \\
$\mathrm{TiO}_{2}$ & $1,91 \%$ & $1,88 \%$ & $2,01 \%$ \\
$\mathrm{~V}_{2} \mathrm{O}_{5}$ & $0,076 \%$ & $0,081 \%$ & $0,083 \%$ \\
$\mathrm{Cr}_{2} \mathrm{O}_{3}$ & $0,077 \%$ & $0,076 \%$ & $0,085 \%$ \\
$\mathrm{MnO}$ & $0,29 \%$ & $0,30 \%$ & $0,35 \%$ \\
$\mathrm{Fe} \mathrm{O}_{3}$ & $24,1 \%$ & $23,7 \%$ & $25,9 \%$ \\
$\mathrm{NiO}$ & $0,02 \%$ & - & - \\
$\mathrm{CuO}$ & $0,084 \%$ & $0,079 \%$ & $0,092 \%$ \\
$\mathrm{ZnO}$ & $0,04 \%$ & $0,04 \%$ & $0,04 \%$ \\
$\mathrm{SrO}$ & $0,60 \%$ & $0,56 \%$ & $0,46 \%$ \\
$\mathrm{MoO} \%$ & $4,5 \%$ & $4,8 \%$ \\
$\mathrm{Eu}_{2} \mathrm{O}_{3}$ & $4,6 \%$ & $0,35 \%$ & $0,40 \%$ \\
$\mathrm{Yb}_{2} \mathrm{O}_{3}$ & $0,35 \%$ & - & - \\
$\mathrm{Re}_{2} \mathrm{O}_{7}$ & $0,05 \%$ & $0,1 \%$ & $0,2 \%$ \\
$\mathrm{P}_{2} \mathrm{O}_{5}$ & $0,1 \%$ & - & $0,62 \%$ \\
\hline
\end{tabular}

Adapun untuk memperoleh silika dengan tingkat kemurnian tinggi dibutuhkan metode sintesis yang dapat menurunkan secara signifikan kadar pengotor dalam sampel tersebut. Silvia \& Zainuri, (2020) telah berhasil mensintesis silika dari pasir alam pantai Bancar yang memiliki kemurnian tertinggi mencapai $100 \%$ dari kandungan awal $81,7 \%$ menggunakan metode kopresipitasi dengan 
pelarut $\mathrm{NaOH}$. Hal ini menunjukkan bahwa metode kopresipitasi ataupun metode lain dapat diterapkan pada sampel yang mengandung silika seperti lumpur panas Sidoarjo untuk memperoleh kemurnian tinggi. Oleh karena itu, lumpur panas Sidoarjo ini juga berpotensi menjadi sumber silika yang memiliki kemurnian tinggi.

\subsection{Hasil Uji XRD}

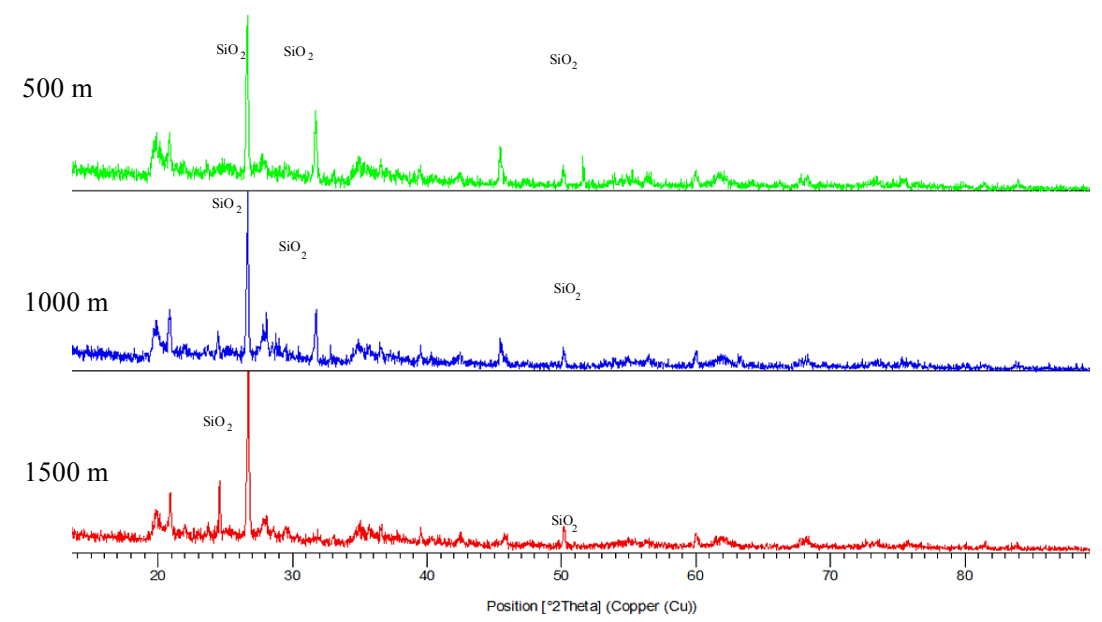

Gambar 5. Hasil difraktogram Lumpur Panas Sidoarjo pada 3 radius berbeda menggunakan XRD

Hasil uji XRD sampel lumpur panas Sidoarjo pada radius 500 m, 1000 m, dan 1500 m dari pusat semburan ditampilkan pada Gambar 5. Berdasarkan Gambar 5 terlihat bahwa spektrum difraksi sinar-x sampel lumpur panas Sidoarjo pada masing-masing radius memiliki kandungan senyawa yang relatif sama. Analisis kuantitatif sederhana ini dapat dilakukan dengan bantuan aplikasi Match! 3. Hasil analisis kuantitatif ini tidak bertujuan untuk memperoleh presentasi setiap fase secara akurat yang terdapat pada sampel. Perhitungan ini hanya dilakukan dengan tujuan untuk mengetahui fasefase dominan pada sampel untuk dapat dibandingkan dengan hasil XRF. Hasil perhitungan ini untuk masing-masing radius ditampilkan pada Gambar 6 (radius $500 \mathrm{~m}$ ), Gambar 7 (Radius $1000 \mathrm{~m}$ ), dan Gambar 8 (Radius $1500 \mathrm{~m}$ ).

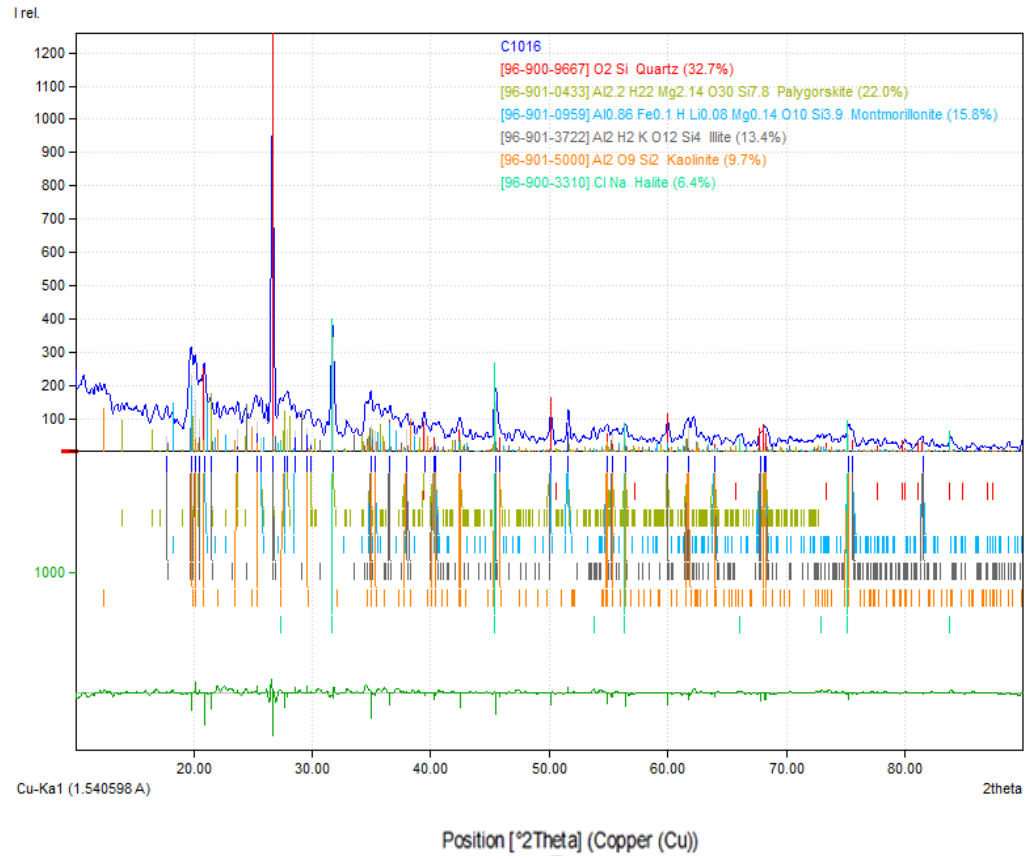

Gambar 6. Hasil analisis kandungan mineral Lumpur Panas Sidoarjo radius 500 m menggunakan $\mathrm{XRD}$ 


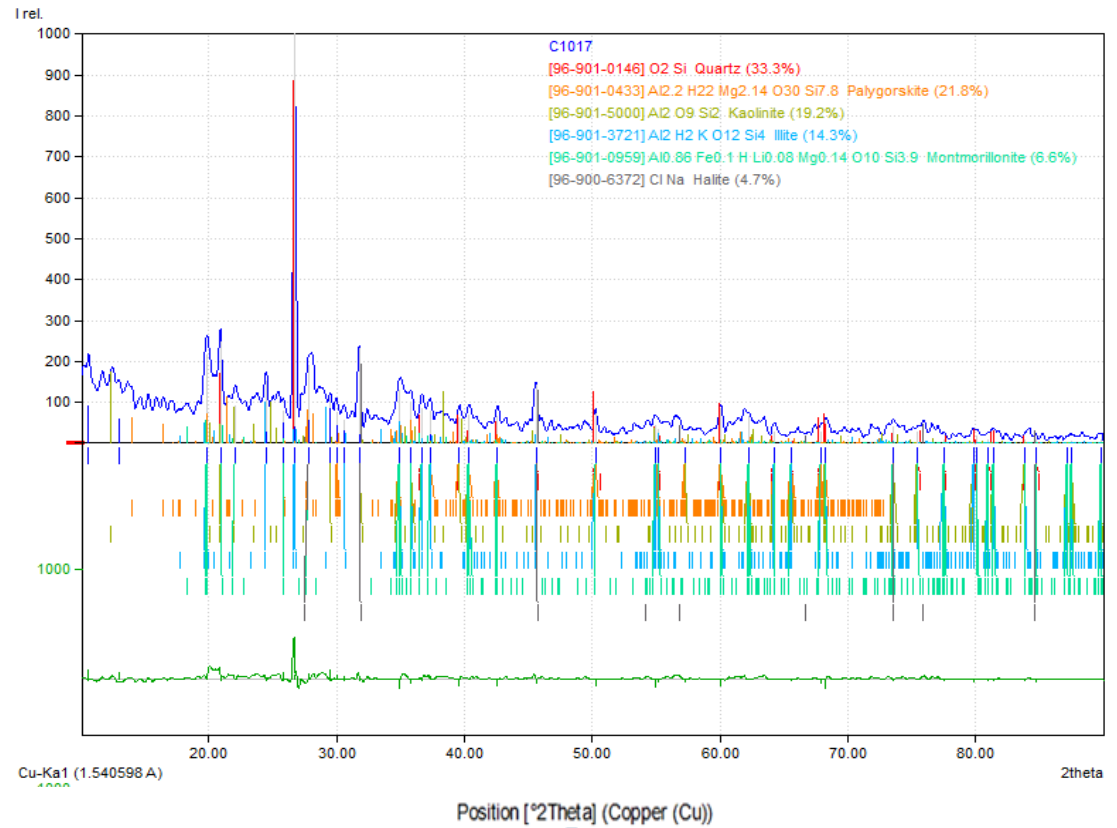

Gambar 7. Hasil analisis kandungan Mineral Lumpur Panas Sidoarjo radius 1000 m menggunakan XRD

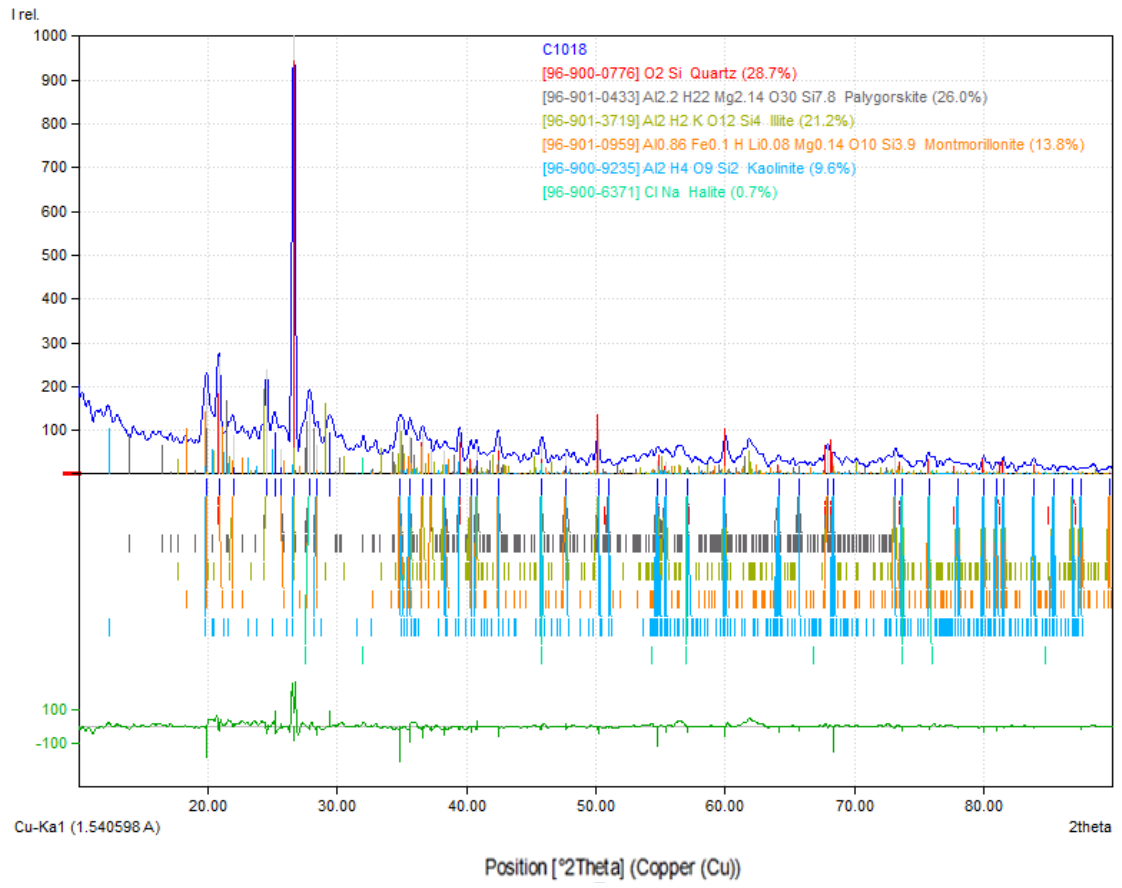

Gambar 8. Hasil analisis kandungan mineral Lumpur Panas Sidoarjo radius 1500 m menggunakan XRD

Hasil perhitungan Match! 3 ini hanya merupakan estimasi kasar mengenai fase-fase dominan pada sampel [18]. Hal ini terlihat dalam Gambar 6, Gambar 7, dan Gambar 8, dimana masih terdapat puncak data difraksi yang tidak terdeteksi dengan pola difraksi terhitung. Berdasarkan hasil analisis kuantitatif sederhana dengan perhitungan Match! 3 menunjukkan bahwa fase paling dominan pada sampel lumpur panas Sidoarjo pada masing-masing radius adalah fase kuarsa $\mathrm{SiO}_{2}$ (silika). Berdasarkan literatur, dalam Florke et al (1986) dimana fase kuarsa dapat ditunjukkan pada bidang

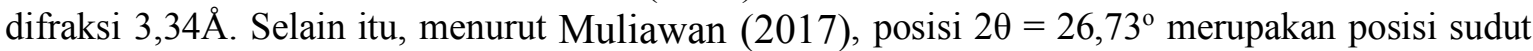
dengan intensitas maksimum dan teridentifikasi sebagai fase kuarsa. Dilihat dari Tabel 3. nilai sudut 
dan bidang difraksi sampel memiliki nilai yang tidak berbeda jauh dari literatur, sehingga dapat dinyatakan sampel teridentifikasi sebagai kuarsa $\left(\mathrm{SiO}_{2}\right)$. Menurut data JCPDS (01-085-0797), puncak utama yang menunjukkan pola difraksi $\mathrm{SiO}_{2}$ pada $2 \theta$ adalah 20,$857 ; 26,64 ; 36,542 ; 39,75$; 50,$141 ; 59,953 ; 68,147$. Data tersebut menunjukkan pola difraksi yang sama dengan penelitian ini. Hasil ini disesuaikan dengan hasil uji XRF yang sudah dilakukan dimana kandungan senyawa oksida terbesar dalam sampel adalah silika $\left(\mathrm{SiO}_{2}\right)$.

TABEL III. Hasil XRD berupa bidang difraksi dan sudut difraksi

\begin{tabular}{ccc}
\hline \multirow{2}{*}{ Sampel } & $2 \theta\left({ }^{\circ}\right)$ & Hasil XRD \\
& 26,6497 & $\mathrm{~d}_{\mathrm{hkl}}(\AA)$ \\
\hline Radius $500 \mathrm{~m}$ & 26,6812 & 3,34504 \\
Radius $1000 \mathrm{~m}$ & 26,7290 & 3,34116 \\
Radius $1500 \mathrm{~m}$ & 3,33530 \\
\hline
\end{tabular}

\subsection{Arah Pemanfaatan Lumpur Panas Sidoarjo sebagai Sumber Silika}

Endapan lempung/lumpur saat ini menjadi salah satu material yang dimanfaatkan dalam berbagai bidang industri hingga dalam bidang katalis. Pemanfaatan endapan lumpur khususnya lumpur panas Sidoarjo ini juga berguna mengurangi surplus endapan yang dihasilkan pada lokasi tanggul tiap harinya [21]. Lumpur panas Sidoarjo dapat dijadikan sumber silika potensial di masa depan yang memiliki banyak manfaat seperti ditunjukkan oleh Gambar 9.

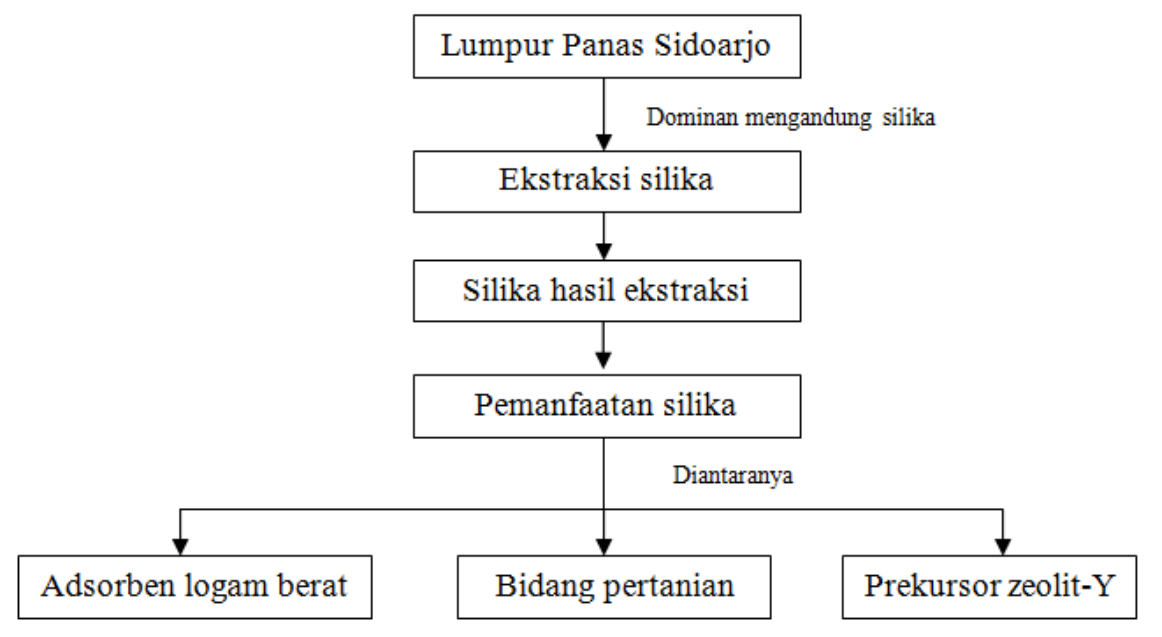

Gambar 9. Alur pemanfaatan silika dari lumpur panas Sidoarjo

\section{Silika sebagai Adsorben Logam Berat}

Kandungan logam berat pada perairan yang berada di atas ambang batas menyebabkan dampak buruk bagi lingkungan dan kehidupan. Beberapa logam berat yang umumnya menjadi polutan perairan yaitu timbal, tembaga, merkuri, kadmium, seng, dan besi. Ada berbagai metode yang dapat dilakukan untuk mengambil logam berat dari perairan, salah satunya dengan cara ekstraksi fasa padat menggunakan adsorben tertentu. Silika merupakan salah satu bahan alam yang dapat dimanfaatkan sebagai adsorben [22]. Silika mampu berperan sebagai adsorben logam berat karena memiliki situs aktif siloksan (Si-O-Si) dan silanol (Si-OH) [8]. Dalam hal ini, siloksan berperan sebagai ligan yang akan menyediakan elektron bebas untuk mengikat kation logam berat.

Beberapa penelitian telah membuktikan efektivitas silika sebagai adsorben logam berat, di antaranya yaitu untuk adsorpsi logam $\mathrm{Cu}$ dan Fe. Dengan menggunakan massa silika sebesar 1,2 gram dan waktu kontak 40 menit, mampu menyerap $\mathrm{Cu}$ sebanyak 94\%. Selain itu, dengan waktu optimum 40 menit, silika mampu menurunkan kadar Fe sebesar 0,142 ppm [8], [23]. Oleh karena itu, salah satu pemanfaatan silika yang terkandung dalam lumpur panas Sidoarjo yaitu berpotensi dijadikan sebagai adsorben logam berat.

Pemanfaatan Silika dalam Bidang Pertanian 
Pemanfaatan silika juga cukup potensial dalam bidang pertanian. Silika merupakan unsur hara non esensial, tetapi memiliki peranan penting dalam menjaga keseimbangan unsur hara tanah. Ketersediaan unsur hara N, P, K, Ca, Mg, S, dan Zn dapat ditingkatkan dengan keberadaan silika. selain itu, silika juga mampu menurunkan stress biotik, abiotik, dan memperkuat jaringan, sehingga tanaman lebih tahan terhadap hama [23]. Tanaman menyerap silika dalam bentuk $\mathrm{Si}(\mathrm{OH})_{4}$, kemudian dipolimerisasi menjadi $\mathrm{SiO}_{2} \cdot \mathrm{nH}_{2} \mathrm{O}$ dan berasosiasi dengan sel epidermis di berbagai jaringan tumbuhan. Dengan adanya asosiasi tersebut, maka dinding sel menjadi lebih kuat dan transpirasi yang berlebihan dapat dicegah [24]. Keberadaan silika dapat menjaga daun tetap tegak, sehingga mampu menstimulasi proses fotosintesis dan translokasi karbondioksida $\left(\mathrm{CO}_{2}\right)$ [25].

Dilansir dari Balai Litbang (2019), pupuk silika telah ada pengembangan formulasi pupuk silika yang diperuntukkan bagi tanaman yang memerlukan kadar silika tinggi, di antaranya yaitu padi dan tebu. Pengembangan komersialisasi pupuk silika sangat tepat dikembangkan bagi agro industri sebagai upaya untuk mencapai ketahanan pangan berkelanjutan. Pupuk silika juga terbukti meningkatkan hasil panen gabah basah per tanaman sebesar $21,3 \%$ dan peningkatan hasil gabah kering per tanaman sebesar 20,0\% [9]. Berdasarkan hal tersebut, maka silika dari lumpur panas Sidoarjo juga dapat dioptimalkan pemanfaatannya sebagai mineral tambahan pada pupuk.

\section{Silika sebagai Prekursor Sintesis Zeolit-Y}

Zeolit adalah mineral aluminium silikat terhidrasi dengan rumus umum $\mathrm{L}_{m} \mathrm{Al}_{x} \mathrm{Si}_{\mathrm{y}} \mathrm{O}_{z} \cdot \mathrm{nH}_{2} \mathrm{O}(\mathrm{L}$ merupakan logam, m , x, y, dan z menunjukkan koefisien $\mathrm{Al}$, Si, dan $\mathrm{O}$ yang nilainya antara 2 hingga 10). Berdasarkan sumbernya, zeolit dibedakan menjadi dua, yaitu zeolit alam dan zeolit sintetis. Zeolit sintesis dibuat dengan menggunakan silika komersial seperti tetraetil ortosilikat [26]. Namun, silika komersial tersebut cukup mahal. Oleh karena itu, sumber silika dari alam yang dapat diperbarui, salah satunya yaitu lumpur Panas Sidoarjo, lebih efektif digunakan untuk memangkas biaya produksi, serta ramah lingkungan. Zeolit yang berbahan baku silika ini bermanfaat sebagai katalisator biodiesel maupun biofuel [10].

Pemanfaatan silika dari lumpur panas Sidoarjo untuk sintesis zeolit-Y dilakukan melalui beberapa tahap. Tahap pertama, yaitu ekstraksi silika untuk mendapatkan silika dengan kemurnian tinggi. Kemudian, melakukan sintesis zeolit-Y dengan metode hidrotermal yang merupakan proses kristalisasi. $\mathrm{SiO}_{2}$ hasil ekstraksi direaksikan dengan $\mathrm{NaOH}$ disertai pengadukan dan pemanasan. Reaksi ini membentuk natrium silikat. Kemudian, direaksikan dengan natrium silikat untuk melalui proses hidrotermal untuk sintesis zeolit-Y. Metode hidrotermal dilakukan pada temperatur dan tekanan yang tinggi $\left(>100{ }^{\circ} \mathrm{C},>1 \mathrm{~atm}\right)$, sehingga reaksinya lebih cepat. Selain itu, kristal yang dihasilkan akan memiliki kemurnian yang tinggi [27]. Zeolit-Y yang telah disintesis dapat dimanfaatkan, salah satunya sebagai katalis berbagi dalam berbagai macam reaksi kimia dan katalis tersebut dapat diregenerasi kembali (reusable).

\section{KESIMPULAN}

Berdasarkan uji XRF dan XRD dapat disimpulkan bahwa kandungan mineral lumpur panas Sidoarjo pada 3 radius berbeda memiliki kandungan yang relatif sama. Kandungan senyawa oksida yang paling besar adalah silika dengan persentase masing-masing radius 45,0 \% (radius $500 \mathrm{~m}$ ), 45,3 $\%$ (radius $1000 \mathrm{~m}$ ), dan 43,3 \% (radius $1000 \mathrm{~m}$ ). Penggunaan metode sintesis yang tepat memungkinkan diperolehnya silika dengan kemurnian yang lebih tinggi sehingga lumpur panas Sidoarjo memiliki potensi sebagai sumber silika. Hasil XRD juga menunjukkan bahwa fase kristal yang paling dominan pada masing-masing sampel adalah fase kuarsa. Besarnya kandungan silika pada lumpur panas Sidoarjo berpotensi untuk dimanfaatkan di berbagai bidang, diantaranya yaitu sebagai adsorben logam berat, pemanfaatan dalam bidang pertanian, dan sebagai prekursor sintesis zeolit-Y. Berdasarkan hasil ini, direkomendasikan untuk dilakukannya penelitian lanjutan mengenai sintesis silika dari lumpur panas Sidoarjo untuk memperoleh kemurnian yang tinggi.

\section{Ucapan Terima Kasih}

Terima kasih diucapkan kepada Kementerian Pendidikan, Kebudayaan, Riset, dan Teknologi yang telah mendanai seluruh penelitian ini melalui Hibah PKM-Riset Eksakta pendanaan tahun 2021 
dan kepada bidang Kemahasiswaan Universitas Negeri Malang yang telah memfasilitasi terselenggaranya hibah PKM-Riset Eksakta pendanaan tahun 2021.

\section{Daftar Pustaka}

[1] R. S. Mustopa and D. D. Risanti, "Karakterisasi Sifat Fisis Lumpur Panas Sidoarjo dengan Aktivasi Kimia dan Fisika," J. Tek. Pomits, vol. 2, no. 2, pp. 256-261, 2013.

[2] E. S. Mochni, A. Budhyantoro, F. Teknik, J. T. Kimia, and U. Surabaya, "Pembuatan batubata dengan bahan baku lumpur sidoarjo," vol. 17, pp. 1-8, 2021.

[3] R. S. Lestari and M. Razif, "Pemanfaatan Lumpur Lapindo Sebagai Batako Menggunakan Pb," Semin. Teknol. Perencanaan, Perancangan, Lingkung. dan Infrastruktur, vol. 2006, pp. 443-449, 2019.

[4] E. A. Yulianto, "Karakteristik Fisik dan Mekanik Lumpur Sidoarjo dengan Kedalaman Bervariasi," Skripsi. Inst. Teknol. Adhi Tama Surabaya, 2009.

[5] S. Sulastri and S. Kristianingrum, "Berbagai Macam Senyawa Silika: Sintesis, Karakterisasi dan Pemanfaatan," Pros. Semin. Nas. Penelitian, Pendidik. dan Penerapan MIPA, Fak. MIPA, Univ. Negeri Yogyakarta, 2010.

[6] Aristianto, "Pemeriksaan Pendahuluan Lumpur Panas Lapindo Sidoarjo," Balai Besar Keramik Dapartemen Perindustrian, Bandung, 2006.

[7] A. F. Fadli, R. T. Tjahjanto, and Darjito, "Silika dalam Lumpur Lapindo Menggunakan Metode Kontinyu," Kim. Student J., vol. 1, no. 2, pp. 182-187, 2012.

[8] M. I. Sholichuddin, Q. Q. Al-Quraisj, and N. D. Siswati, "Seminar Nasional Teknik Kimia Soebardjo Brotohardjono Xvii," In Pemanfaatan Silika Xerogel Dari Abu Sekam Padi Sebagai Adsorben Logam Berat $\mathrm{Cu}, 2021$, pp. 66-73.

[9] Sugiyanta, I. M. Dharmika, and D. S. Mulyani, "Application of Liquid Silica Fertilizer to Increase Growth, Yield, and Drought Tolerance in Rice," Indones. J. Agron., vol. 46, no. 2, pp. 153-160, 2018, [Online].

Available: https://www.researchgate.net/publication/328142944_Pemberian_Pupuk_Silika_Cair_untuk_Meningk atkan_Pertumbuhan_Hasil_dan_Toleransi_Kekeringan_Padi_Sawah.

[10] S. Norvia, Suhartana, and Pardoyo, "Dealuminasi Zeolit Alam Menggunakan Asam ( $\mathrm{HCl}$ dan $\mathrm{H} 2 \mathrm{SO} 4$ )," J. Kim. Sains dan Apl., vol. 19, no. 2, pp. 72-76, 2016.

[11] Sumari, D. R. Baharintasari, M. R. Asrori, and Y. F. Prakasa, "Analisis Kandungan dari Pasir Pantai Peh Pulo Kabupaten Blitar Menggunakan XRF dan XRD,” J. Fis. Fis. Sains dan Apl., vol. 4, no. 2, pp. $52-55,2019$.

[12] Jamaluddin, A. Darwis, and M. A. Massinai, "X-Ray Fluorescence (XRF) to identify chemical analysis of minerals in Buton island, SE Sulawesi, Indonesia," IOP Conf. Ser. Earth Environ. Sci., vol. 118, no. 1, 2018, doi: 10.1088/1755-1315/118/1/012070.

[13] A. Assolah, "Sintesis dan Karakterisasi Zeolit X dari Lumpur Lapindo dengan Variasi Komposisi SiO2/A12O3 Menggunakan Metode Sol-Gel," Skripsi. Univ. Islam Negeri Maulana Malik Ibrahim, 2015.

[14] A. Juniawan, B. Rumhayati, and B. Ismuyanto, "The Effect of Carbon Organic Total and Salinity on The Discharge of Heavy Metals $\mathrm{Pb}$ and $\mathrm{Cu}$ in Lapindo Mud into The Aloo River," J. Pure Appl. Chem. Res., vol. 1, no. 1, pp. 41-50, 2012, doi: 10.21776/ub.jpacr.2012.001.01.105.

[15] W. R. Tamara, Sumiyati, and I. M. A. S. Wijaya, "Analisis Kualitas Sifat Fisik Tanah pada Lahan Subak di Bali,” J. Beta (Biosistem dan Tek. Pertanian), vol. 8, no. 2, pp. 358-363, 2020.

[16] Amrin and D. Ardilla, "Analisis Besi ( Fe ) dan Aluminium ( Al ) Dalam Tanah Lempung Secara Spektrofotometri Serapan Atom,” Pros. Semirata FMIPA Univ. Lampung, pp. 17-22, 2013.

[17] L. Silvia and M. Zainuri, "Analisis Silika (SiO2) Hasil Kopresipitasi Berbasis Bahan Alam menggunakan Uji XRF dan XRD," J. Fis. dan Apl., vol. 16, no. 1, p. 12, 2020, doi: 10.12962/j24604682.v16i1.5322.

[18] R. K. Pingak, A. Z. Johannes, and L. A. S. Lapono, "Analisis Potensi Pasir Tablolong Dan Pasir Koka Sebagai Sumber Silika Menggunakan Uji XRF Dan XRD,”J. Fis. Fis. Sains dan Apl., vol. 3, no. 3, pp. 
132-136, 2018, doi: 10.35508/fisa.v3i3.614.

[19] Florke, Ow, and H. Schneider, "Verwachsungsbeziehung n Der Sio2-Polymorphe Quarz, Cristobalit Und Tridymit In Sio2- Reichen Keramischen Werkstoffen. Paper read at CFI.," Ceram. forum Int., vol. 63, no. 7-8, pp. 368-372, 1986.

[20] A. Muliawan, "Studi Awal Bahan Dasar Piranti Solar Cell Pada Pasir Sambera Muara Badak Menggunakan XRF dan XRD,” TURBO, vol. 6, no. 2, pp. 117-122, 2017.

[21] T. Winarno, Y. B. A. Gunawan, and J. Marin, “Analisis Mineralogi dan Kandungan Kimia Endapan Lumpur Sidoarjo dan Arah Pemanfaatannya," Teknik, vol. 40, no. 2, p. 91, 2019, doi: 10.14710/teknik.v39i3.21742.

[22] N. T. Widodo, A. Mulyasuryani, and A. Sabarudin, "Recovery Cu ( II ) dengan Teknik Ekstraksi Fasa Padat Menggunakan Adsorben Silika dari Abu Sekam Padi - Kitosan,” Nat. B, vol. 2, no. 4, pp. 360$365,2014$.

[23] I. S. Hardyanti, I. Nurani, D. Septyaningsih, H. Hp, E. Apriliani, and E. A. Prastyo, "Pemanfaatan Silika ( SiO 2 ) dan Bentonit sebagai Adsorben Logam Berat Fe pada Limbah Batik Batik merupakan salah satu kekayaan budaya bangsa Indonesia yang telah mendapat pengakuan internasional dari UNESCO pada setiap tahun . Pada tahun 2010 nilai produ," J. Sains Terap., vol. 3, no. 2, 2017.

[24] J. F. Ma and N. Yamaji, "Silicon Uptake and Accumulation in Higher Plants.," J. Okayama Univ., 2006.

[25] A. T. Sari, S. W. Suedy, and S. Haryanti, "Pengaruh pupuk nanosilika terhadap pertumbuhan dan Produksi tanaman kapas (Gossypium hirsutum 1. Var. Kanesia," IEEE Int. Conf. Acoust. Speech, Signal Process. 2017, vol. 41, no. 2, pp. 84-93, 2017.

[26] S. Kulawong, S. Youngjan, P. Khemthong, N. Chanlek, J. Wittayakun, and N. Osakoo, "Magnesium impregnated on nax zeolite synthesized from cogon grass silica for fast production of fructose via microwave-assisted catalytic glucose isomerization," Catalysts, vol. 11, no. 8, 2021, doi: 10.3390/catal11080981.

[27] D. Rahmawati and B. Irawan, "Laporan penelitian Pembuatan granul monetite menggunakan metode hidrotermal sebagai kandidat bone graft kedokteran gigi," 2021. doi: 10.24198/jkg.v33i2.34406.

[28] R. Syahputra, R. U. Permata, M. Hilmiati, N. Arif, and A. E. Fitriati, "Efek Konsentrasi Katalis OH - zeolit pada Produksi Biodiesel dengan Metode Elektrolisis,” Pros. Snips 2017, no. June, pp. 7-13, 2017.

Jurnal IJCA is licensed under aÂ Creative Commons Attribution ShareAlike 4.0 